\title{
The Effect Of Reciprocal Instructional Models And Interpersonal Intelligence On The Student Learning Outcomes Of Social Science Education
}

\author{
Muhamad Abas, Etin Solihatin, Nadiroh
}

\begin{abstract}
This study aims to examine the effect of reciprocal instruction and interpersonal intelligence on student learning outcomes. This research was conducted on UHO PGSD students who programmed the subject of Social Sciences elementary school in 2018/2019. This study used a quasiexperimental method, with a non-equivalent post-test control group design. The research sample was taken with simple random techniques. The experimental class and the control class each consisted of 47 students. The experimental class is taught with reciprocal learning models while the controls are traditional learning models. Each class was taken $27 \%$ or 26 students from each class as a sample. The sample determination was based on the division of high and low interpersonal intelligence, each of $27 \%$ of the total population. So that the total sample as a whole is 52 students. Before being given treatment, the two classes were first given an interpersonal intelligence questionnaire to obtain high and low intelligence data. Data on learning outcomes are obtained through multiple choice form tests. Before use, the questionnaire instrument and the test were first validated by content and constructs by education and psychology experts. then an empirical test is carried out, the result is a validity value of 0.91 and a reliability of 0.93 . The research data were analyzed by descriptive and inferential analysis. Hypothesis testing is carried out with 2 way ANOVA. Then the normality and homogeneity tests were carried out as a prerequisite test for the hypothesis test. Furthermore, if there is interaction, further testing is carried out with the HSD test to find out the main effects of the treatment. Data processing results of this study were carried out with the help of the SPSS 20. The results showed that there were differences in student learning outcomes taught by reciprocal and traditional models. Furthermore, there is an interaction between learning models and interpersonal intelligence. Students who have high interpersonal intelligence have better learning outcomes than students who have low interpersonal intelligence. Thus it can be concluded that students who have high interpersonal intelligence taught by reciprocal models have better learning outcomes than students taught with traditional models
\end{abstract}

Index Terms: Reciprocal Instructions; Interpersonal Intelligence; Learning Outcomes.

\section{INTRODUCTION}

Social Sciences is a field of study oriented to the development of knowledge and strengthening values. (Susanto, 2014; Sapariya, 2011). To make it happen, an interactive learning model is needed that creates participatory learning. The material of Social Sciences is an

Revised Manuscript Received on April 19, 2019.

Muhamad Abas, Student of Post-Graduate of Universitas Negeri Jakarta, Lecturer Of Halu Oleo University, Sulawesi Tenggara, Indonesia.

Etin Solihatin, Universitas Negeri Jakarta , Jakarta, Indonesia.

Nadiroh Universitas Negeri Jakarta, Jakarta, Indonesia.
(Email: muhamadabas750@gmail.com)

integration of various fields of social science. Integration is intended to familiarize students in solving social problems with an integrative approach. The shift of learning paradigm from behavioristic to constructivist has consequences for the emergence of various learning models. Each learning model is always oriented to the meaningfulness of the process and achievement of performance. Some models of learning in social studies have been developed over the past 20 years. Among them are problem-based learning, demonstration learning i.e., expository, direct, cooperative, experiencebased, social inquiry, and integrative learning. Each model has a special emphasis developed to meet the diverse needs of students. The practice of social studies in the UHO PGSD environment still makes many conventional methods such as lectures, question and answer, and discussion as to its mainstay. Students are directed at the ability to memorize and remember various facts and concepts. Without being required to understand and connect with social facts in the community. Lecturers are still considered the main learning source and students are played as recipients of the information. The demands of the high grade of final graduation compel lecturers to prioritize mastery of intellectual skills. This results in the success achieved only at the level of high academic value while the aspects of developing the concept of understanding skills are neglected. This is important for developing cognitive abilities and critical thinking skills. The development of the ability to understand concepts cannot be separated from the interaction process between students, lecturers, and their environment. Reciprocal learning emphasizes the importance of interpersonal relationships in learning. IPS learning material can be well understood if there is a mutual exchange in the form of dialogue. While the dialogue is one characteristic of reciprocal learning models. Wahida and Yaacob (2016) in their study of developing children's potential through interpersonal and intrapersonal activities suggested to teachers the importance of enrichment activities or guidance in maximizing children's potential. This shows that interpersonal intelligence has an influence on the achievement of children's performance in learning. For this reason, students must be trained to learn from their peers through group activities to hone various cognitive abilities. The ability to interact in a social environment is one of the main components of interpersonal intelligence. 
According to Armstrong (2009) and Anderson (2001), interpersonal intelligence is the ability to understand and make differences and respond effectively to various interpersonal cues that include social sensitivity dimensions, social insight, and social communication. Understanding of lecturers on the diversity of students in terms of intelligence is very important to consider when determining the learning model used. Ahmed (2012) in his study found a relationship between learning models and student intelligence on learning outcomes. Likewise, the results of Wahid's study (2016) comparing the effectiveness of the Jigsaw and traditional learning models concluded that there were significant differences in learning outcomes between students who used the jigsaw learning strategy and students using traditional learning. Learning outcomes with jigsaw learning strategies are more effective than traditional learning strategies. From the two results of the study, it was shown that students' understanding of the material was not merely determined by the choice of learning models used but also influenced by intelligence factors. Eggen and Kauchack (2010) explain that intelligence is the ability of each individual that can be used to solve problems and adapt to the environment. This shows that the collaboration between students in understanding learning materials must be a concern in the application of learning models. One learning model that emphasizes collaboration and dialogue in class is the reciprocal learning model. This learning model allows students to support and cooperate with each other to complete tasks in the learning process. Students can collaborate to discuss material both in small groups and in discussions during presentations. In this case, it does not only require mutualism in learning but also requires students to take responsibility independently for the success of their learning. This requires the understanding of lecturers on the social intelligence of each individual. Intelligence is related to the success of social relationships to cooperate with others effectively. Schunk (2012) explains that interaction with people around the environment stimulates developmental processes and encourages cognitive growth which he later calls interaction between interpersonal factors. Gilakjani's study (2012) concluded that reciprocal teaching is very effective in improving students' reading comprehension skills. Furthermore, Tseng \& Chin Yeh (2018) in his study concluded that reciprocal teaching was more effective in improving the ability to read English than a question and answer strategy. Yu-Fen Yang (2010), in his research on developing reciprocal teaching, suggested the importance of teachers encouraging students to interact with their friends in discussing the understanding of the material. Furthermore, in the learning process, the teacher must monitor the development and independence of students in understanding reading. But the study of Zendler \& Reile (2018) when comparing reciprocal and programmed learning methods found that programmed learning was more effective than reciprocal teaching in computer learning. From some of these studies, there is a diversity of findings from researchers related to the application of reciprocal learning in class. But no one specifically examines the effect of reciprocal teaching and interpersonal intelligence on social studies learning outcomes. Therefore this study focuses on the study on (1) whether there are differences in student learning outcomes taught by reciprocal and traditional learning. (2) Is there an influence of interaction between learning models and interpersonal intelligence (3). Are there differences in the learning outcomes of students who have high interpersonal intelligence and low interpersonal intelligence. Thus it is hoped that this research can contribute to the development of science, especially learning models and can be practically used in the process of social studies learning in higher education.

\section{LITERATURE REVIEW}

Understanding of concepts is a form of cognitive and affective depth that is owned by each individual. This is a manifestation of individual cognitive processes in receiving and understanding information obtained through learning. Anderson and Krathwohl (2010) describe cognitive processes which include remembering, understanding, applying, analyzing, evaluating and creating. Marzano (2011), grouping it into high-level cognitive, moderate level cognitive and low level cognitive. In line with that, Sapriya (2012) and Rahman (2014) explained that the achievements of social studies education included the dimensions of knowledge, skill, value and attitude and action. Lovat and Toomey (2011) stated that "Quality teaching is the" dynamic interaction of subject content, pedagogical strategies, and values to provide an optimal environment for student achievement. Based on the description, it can be explained that social studies learning outcomes are behavioral changes that include cognitive, affective and psychomotor dimensions obtained after students follow and complete their learning programs. Bruce and Djaali (2008) explains that tests can be used to measure the amount of knowledge an individual acquires from a subject matter that is limited to a certain level. Thus, social studies learning outcomes are all changes in behavior that occur in students who are pleased with the IPS learning material. This includes cognitive ability and mastery of social studies material. One learning model that is in accordance with student cognitive development is a reciprocal learning model.

Palincsar (2012) explains that reciprocal learning is a series of learning procedures in which students carry out cognitive activities with their peers and teachers. Learning is focused on specific and concrete strategies to improve understanding of learning material through dialogue. Doolittle et al., (2012) explains that reciprocal learning models encourage students to be more active in their roles in groups, helping students to better understand the material given by the teacher, and with this model can improve students' cognitive. Thus it can be understood that reciprocal learning can hone the ability of students to explore the material through collaboration by asking questions, explaining, summarizing and predicting. Reciprocal learning is in line with the assumption of cognitive learning theory in which learning takes place through the construction and conversion of cognitive structures. Zendler, 2018) explains that the role of students actively processes information, and rearranges it according to their understanding. The progress 
of student learning in reciprocal learning is controlled by the teacher as well as controlled by students themselves. Theoretically, reciprocal learning is related to the theory of the zone of proximal development. Vygotsky (1978) explains that a child has two levels of development (1) the level of actual development, namely where children can independently handle the task. (2) the level of potential development, namely the rate at which a child can solve a problem with the help of a teacher or collaboration with other children. Palincsar (2012) calls it scaffolding as a way to guide children at that stage. This scaffolding activity is given to students who need help because of the delay in understanding the material. In the study of Jenifer \& Osana (2013), it was explained that reciprocal learning can provide two advantages, namely rational theory and the writing of concept ideas well when learning is done. Among them, the reciprocal model can encourage students to collaborate, respond to problems and leadership, can generate student motivation, build social relationships with other students, and can reduce student noise in the classroom. Slavin (2012) and Mazarno (2012), explained that reciprocal models would encourage collaboration, response, and leadership, foster motivation, build social relationships, and reduce poor behavior in the classroom. This advantage relates to factors that influence student learning outcomes between school, psychological, facilities, and teachers. Furthermore, Palincsar (2012) explains the weakness of the reciprocal learning model lies in the quality of the dialogue. This weakness is directed at the teacher and students who are the implementers. Reciprocal learning is often also referred to as dialogic learning, namely dialogue between teachers and students in learning to understand the meaning of the material. Spörer et al., (2009) explains that the use of reciprocal learning in natural science has a positive impact on improving reading comprehension in students. In the early stages of reciprocal learning, the teacher has the primary responsibility of modeling the process of using reciprocal learning steps. After that, students practice the strategy. The teacher supports each student's participation through feedback, additional modeling, training, instructions, and explanations. Therefore this model can hone students' social skills as well as critical thinking skills through dialogue. To realize this, it is necessary to pay attention to the diversity of student intelligence. Gardner (2011) in Frame of Mind: Theory of Multiple Intelligences explains that all humans have many intelligences, including linguistic, logical-mathematical, musical, spatial, kinesthetic, interpersonal, intrapersonal, and naturalist intelligence. (1) Linguistic intelligence involves spoken and written language. This is the ability to learn languages, and the capacity to use language to achieve certain goals. This intelligence includes the ability to use language effectively to express themselves. (2) Logical-mathematical intelligence involves the capacity to analyze problems logically, carry out mathematical functions, and investigate problems scientifically. This includes the ability to detect patterns, reason deductively and think logically. (3) Kinesthetic intelligence involves the potential to use the entire body or parts of one's body to solve problems by using mental abilities to coordinate body movements. (4) Spatial intelligence is the potential to recognize and use spatial patterns and be associated with one's visual capacity. (5) Interpersonal intelligence is related to the capacity to understand the intentions, motives, and desires of others This allows people to work effectively with others. Educators need interpersonal intelligence to develop well. (6) Intrapersonal intelligence requires the ability to understand oneself, to appreciate one's feelings, fear and motivation. In Gardner's view, it involves having an effective working model of ourselves, and the ability to use that information to regulate our lives. (7) Naturalist intelligence related to the classification ability or flora and fauna of the environment.

Among the many bits of intelligence as explained above, this study only focuses on interpersonal intelligence. Interpersonal intelligence is also commonly referred to as social intelligence, namely the ability to interact and adapt to its social environment. Armstrong (2009), Gardner (2011), and Tirri, at all., (2013). states that interpersonal intelligence is the ability to understand the thoughts, attitudes, and behavior of others and the ability to respond effectively to various interpersonal cues. Furthermore Safaria (2005), Anderson (2011), and Mirzaei, at all., (2014) explain that interpersonal intelligence has three main dimensions, namely social sensitivity, social insight, and social communication. Characteristics of children who have high interpersonal intelligence will always show the ability to develop effective social relations, empathize with others, ability to maintain social relations, sensitive to changes in social situations, able to solve problems well and prevent problems in social relations and have the ability and effective communication skills. Social studies teachers must be aware that students have different strengths, learning styles, and even different learning potential. The teacher must create a learning environment that is suitable for each student. Based on the literature review, it is assumed (1) student learning outcomes taught with reciprocal models are better than students taught with traditional models (2) there is an influence of interaction between learning models and interpersonal intelligence (3) learning outcomes of students who have interpersonal intelligence elevation is better than students who have low interpersonal intelligence.

\section{METHODOLOGY}

This study uses a quasi-experiment method. The research variable consisted of independent variables, moderators, and dependent variables. The independent variables are reciprocal and traditional learning. The moderator variable is high and low interpersonal intelligence. The dependent variable is learning outcomes. The study was conducted at the FKIP PGSD students of Halu Oleo University who programmed the elementary school social studies course The population of this study was all PGSD students in the third year of 2018/2019, totaling 92 students. The research sample was taken by simple random sampling. This study uses the posttest non-equivalent control group design. The instruments used in this study are grouped into two types, namely (1) instruments for measuring interpersonal 
International Conference on Recents Advancements in Engineering and Technology (ICRAET-18) |15th and 16th March 2019|Siddhartha Institute of Technology \& Sciences, Telangana, India.

intelligence using questionnaires, in the form of statements, answers to each statement using a Likert scale (scale 1-5). (2) instruments for measuring learning outcomes use multiple choice tests with alternative answers, if the value is correct one and if the wrong value is zero. Before being used as a data collection tool, the two instruments were first validated by education and psychology experts. After testing on another class, then the validation and reliability test of the instrument was carried out. The result is that the instrument has a validity of 0.91 and a reliability of 0.93 . Before being given treatment in the experimental and control classes, interpersonal intelligence tests were conducted to determine students who had high and low interpersonal intelligence with a distribution of $27 \%$. from the highest score group and $27 \%$ from the lowest score group. Thus it was found a sample of 52 students consisting of 26 experimental class students and 26 control classes. At the end of the study, interviews were conducted with 6 students (each of the 3 students from the control class experimental class) to find out their views regarding the learning model. The research data use descriptive and inferential analysis. Descriptive analysis to display data in the form of averages, medians, and standard deviations. while the hypothesis test is carried out by ANOVA test. This test requires data normality and homogeneity. Nomination test using the Kolmogorov-Smirnov One-Sample test. The homogeneity test uses the Levene test. Whereas to determine the difference in the main influences from the treatment carried out by post hoc Least Significant Difference (LSD) test. Data analysis was performed using the help of a computer program processing SPSS version 20 statistical data

\section{RESULTS AND FINDINGS}

Based on the score of student learning outcomes showed a difference in the average learning outcomes of students taught by reciprocal models and students taught with traditional models. The average score of student learning outcomes taught by reciprocal models is 30.73 and taught by traditional models is 28.19 . on a generic basis, the average student achievement score that has high interpersonal intelligence is 32.38 and students who have low interpersonal intelligence are 26.54. then the statistical data on student learning outcomes scores are shown in table 1 below.

Based on the results of normality test data using the Kolmogorov-Smirnov test shows the significant value of the reciprocal learning model, $\mathrm{P}=200$ and traditional, $\mathrm{P}=194>$ 0.05 shows that the learning outcome data score is normally distributed. Furthermore, the homogeneity test uses a leven test with a significance value of $0.31>0.05$, indicating the variance of homogeneous data. Thus the learning outcomes data are normal and homogeneous. Then proceed with the two-way ANOVA test, the results as presented in table 2 below.
Table 2: Anava Summary Tests

\begin{tabular}{|c|c|c|c|c|c|}
\hline Source & $\begin{array}{l}\text { Type } \\
\text { III Sum } \\
\text { of } \\
\text { Squares }\end{array}$ & Df & $\begin{array}{l}\text { Mean } \\
\text { Square }\end{array}$ & $\mathbf{F}$ & Sig. \\
\hline $\begin{array}{l}\text { Corrected } \\
\text { Model }\end{array}$ & $\begin{array}{l}611.846 \\
\mathrm{a}\end{array}$ & 3 & 203.949 & 23.360 & .000 \\
\hline Intercept & $\begin{array}{l}45135.0 \\
77\end{array}$ & 1 & $\begin{array}{l}45135.0 \\
77\end{array}$ & $\begin{array}{l}5169.65 \\
6\end{array}$ & .000 \\
\hline $\begin{array}{l}\text { Instruction } \\
\text { Model }\end{array}$ & 83.769 & 1 & 83.769 & 9.595 & .003 \\
\hline $\begin{array}{l}\text { Intelligence } \\
\text { Instruction }\end{array}$ & 444.308 & 1 & 444.308 & 50.890 & .000 \\
\hline $\begin{array}{l}\text { Model * } \\
\text { Intelligence }\end{array}$ & 83.769 & 1 & 83.769 & 9.595 & .003 \\
\hline Error & 419.077 & 48 & 8.731 & & \\
\hline Total & $\begin{array}{l}46166.0 \\
00\end{array}$ & 52 & & & \\
\hline $\begin{array}{l}\text { Corrected } \\
\text { Total }\end{array}$ & $\begin{array}{l}1030.92 \\
3\end{array}$ & 51 & & & \\
\hline
\end{tabular}

Anova results show that there are significant differences between reciprocal and traditional learning outcomes. Based on table 2 , then hypothesis 1 which says that there are differences in student learning outcomes taught by reciprocal models and traditional learning, validity, which is indicated by the value of $F=9.595$, with significance, 003 $<.05$. The results of the second hypothesis test obtained the value of $F=9.595$, with a significance value of $P=.003$ $<$ from .05, indicating that there is an interaction between the learning model and interpersonal intelligence. The results of the third hypothesis test obtained a value of $F=50,890$, with a significance of .003> .05 indicating that based on interpersonal intelligence there are differences in student learning outcomes. Furthermore, in table 3 the results of further tests using the LSD test show that the students' learning outcomes for those who have high interpersonal intelligence are better than students who have low interpersonal intelligence. As presented in table 3 below.

Table 3: LSD Summary Test

Models Intelligence Mean Std. Error

\begin{tabular}{llll}
\hline \multirow{2}{*}{ Reciprocal } & High Interpersonal & 34.923 & .820 \\
& Low Interpersonal & 26.538 & .820 \\
\hline \multirow{2}{*}{ Traditional } & High Interpersonal & 29.846 & .820 \\
& Low Interpersonal & 26.538 & .820 \\
\hline
\end{tabular}

Some important findings in the study revealed that the use of reciprocal learning models in learning elementary school social studies is able to improve student learning outcomes. In addition, significantly the reciprocal learning model is able to improve student learning outcomes. This learning model involves students actively in the learning process because students are actively involved in questioning, clarifying, predicting and summarizing strategies. The results of the interview found that students who have high 
interpersonal intelligence are able to explore learning material specifically related to solving problems that arise in the learning process. Students are involved in constructing and connecting their previous knowledge with new information. Slavin (2012) describes constructivist learning to enable students to dialogue and work together to understand abstract concepts. This is relevant to learning elementary school social studies. Where students are required to understand the material clearly through discussion activities.

The use of reciprocal learning models also has a positive effect on the active role of students in social studies learning because with the four existing strategies students are able to well understand the relationships between concepts in learning material. The experimental group likes reciprocal strategies because it is easy to understand the material being studied and arouse their interest in learning. Students from the experimental group are also involved in fun learning while arranging concepts and facts through the process of clarifying and summarizing. Students who have high interpersonal intelligence are also happy to do group presentations and receive lots of input from friends and lecturers in the class. The concept of pleasant learning and active involvement in the learning process has increased students' interest in learning. But for students who have low interpersonal intelligence, they are not very active in clarifying and predicting strategies. They are more happy and active in questioning and summarizing strategy. By Korena, the lecturer took part in giving scaffolding to students who have low interpersonal intelligence, especially in the strategy of clarifying and predicting. Scaffolding is given so that students can participate in adjusting to the development of groups of students who have high interpersonal intelligence.

As shown in table 1, the scores on student learning outcomes that have high interpersonal intelligence taught by reciprocal learning models are better than students taught with traditional learning models. Reciprocal learning provides opportunities for students to explore content learned through dialogue and discussion in the classroom. During the learning process students are required to play an active role in exploring their knowledge and dialogue with their colleagues and lecturers in an interactive process. Yu Fen Yang (2010), in his research, found that reciprocal learning with questioning steps, clarification can improve student understanding. This is because there is an atmosphere of interaction between students that increases understanding and cognitive abilities. Reciprocal learning is in line with the characteristics of social studies learning materials that require students to be able to understand the material through a process of collaboration and discussion in a group. The role of students in reciprocal teaching is as a student and teacher who focuses on the realization of mutual exchange through the dual roles of students. This emphasizes the importance of behavioral modeling in the learning process to help students develop their cognitive skills. Gillies (2014) in his study explained that the learning model emphasizes the interaction and collaboration between students better learning outcomes than the learning model dominated by lecturers in the learning process. In line with that, Mulyono (2018) in his study found that reciprocal learning can improve student learning outcomes. Social studies education will be very interesting if the learning process that occurs emphasizes the effort to build the cognitive potential of students through a process of conducive interaction between students and their learning environment. This interaction will result in the exchange of experience and knowledge so that it can improve the quality and achievement of learning outcomes. According to Zendler \& Reile (2018), reciprocal learning models can improve effectiveness in the learning process. This is evident from the results of this study which shows the achievement of learning outcomes of students who study with reciprocal models higher than students who are taught with traditional learning.

As in table 2, there appears to be an interaction between the learning model and interpersonal intelligence. This is indicated by the acquisition of the value of $\mathrm{F}=5,595$ with significance $P=0.003<0.05$. Daat interpreted that interpersonal intelligence and learning models significantly influence the results of student learning. The reciprocal learning model requires students to be active in dialogue in the classroom. Students who have high interpersonal intelligence have the ability to work together and have a dialogue. This ability can increase his mastery of learning material while at the same time increasing his thinking skills. This is in line with the characteristics of reciprocal learning models that emphasize social dialogue in the learning process. Widyasari (2016) in his study explained that interpersonal intelligence contributes positively to learning outcomes. Thus the learning model and interpersonal intelligence interact positively in supporting student learning outcomes. Safaria (2005, Anderson (2011) and Mirzaei et al., (2014) explain that interpersonal intelligence has three main dimensions namely social sensitivity, social insight, and social communication. Characteristics of children who have interpersonal intelligence will always show the ability to develop social relations effective, empathetic with others, ability to maintain social relations, sensitive to changes in social situations, able to solve problems well and prevent problems in social relations, and have effective communication skills and abilities. This is in line with the understanding that each learning model used in class always requires interaction. The ability of interaction and communication is a character of interpersonal intelligence. Thus the learning model will be very effective to use when interacted with intelligence in the teaching and learning process. Therefore lecturers in choosing the learning model need to understand the characteristics of their students well. Every student has heterogeneous characteristics. The meaningful learning process always requires students' ability to build interactive relationships in the learning process. According to Schunk (2012) and Slavin (2011), the learning model is a pattern or plan to design learning in the classroom. Further explained that learning as an effort to create an environment to facilitate students learning. Therefore, the learning model must be seen as an ecosystem where in the students learn 
and interact. The results of the Study of Jenifer et al., (2013) found the influence of the learning model in enhancing the ability to understand concepts. In connection with that, the intelligence possessed by each student will contribute to the effectiveness of the learning outcomes obtained.

In table 3 , it shows that descriptively the score obtained by students who have high interpersonal intelligence is better than students who have low interpersonal intelligence. This is indicated by the average score of students who have high interpersonal intelligence of 34,923 in reciprocal learning and 29,846 in traditional learning. While for students who have interpersonal intelligence obtain an average score of 26,538 both in reciprocal learning and direct learning. This shows that high interpersonal intelligence has a significant effect on learning outcomes. It can also be interpreted that student learning outcomes are influenced by student interpersonal intelligence. Interpersonal intelligence is often also referred to as social intelligence, namely the ability to interact and adapt to its social environment. Students who have high interpersonal intelligence have the ability to cooperate and build interactions with others. Gardner (2011) explains that interpersonal intelligence is related to the capacity to understand the intentions, motives, and desires of others. This allows people to work effectively with others. Students who have high interpersonal intelligence easily adapt themselves to the learning environment. However, students who have low interpersonal intelligence are more likely to dislike learning models that demand discussion and presentation as well as reciprocal learning models. In his study Wahida \& Yaacob (2016) said the importance of developing children's potential through interpersonal and intrapersonal activities through enrichment activities or mentoring. IPS study material is difficult to understand if only listening to lectures from lecturers but must be deepened through discussion and dialogue. Thus the traditional learning model is less suitable to be applied to students who have high interpersonal intelligence. Students who have low interpersonal intelligence always experience difficulties in communicating their thoughts so that when taught using reciprocal learning models or directly they do not affect their learning outcomes. The typology of students who have low interpersonal intelligence is less like discussion and collaboration in learning. The impact is that understanding the lecture material carried out through discussion cannot be well understood.

\section{CONCLUSION}

Based on the findings of this study, it can be concluded that (1) there are differences in learning outcomes of student social studies taught by reciprocal learning and traditional learning models. Reciprocal learning is more effectively taught to students in social studies subjects than using traditional learning. It was shown in the findings of this study that the average score of students' social studies learning outcomes using reciprocal models was higher than that of students who were taught with direct learning models (2) There was an influence of interaction between learning models and interpersonal intelligence. Thus the selection of learning models in teaching students needs to pay attention to student characteristics (3) Students who have high interpersonal intelligence have higher learning outcomes than students who have low interpersonal intelligence.

Thus it is suggested that the reciprocal learning model can be used as an option for IPS lecturers in conducting learning. Lecturers in choosing learning models need to pay attention to student characteristics and material. In order for the choice of a learning model to be used, it can respond to the diversity of intelligence possessed by students. Besides, lecturers always use scaffolding in the learning process. So that students who have limited ability to understand the material can adjust and follow learning well. Therefore lecturers must always be innovative by developing and using learning models. For all of that, the attention of universities is needed in creating an atmosphere conducive to learning. Including providing adequate supporting facilities for learning activities. Because this study has limitations, it is suggested to other researchers to conduct further studies related to reciprocal learning models, especially other variables that have not been studied by this study.

\section{REFERENCES}

1. Ahmed Gasm Alseed Ahmed (2012), The Relation between multiple intelligences theory and methods of ELT" International Journal of Learning and Teaching, Vol, 4 (2), No. pp. 26 - 41.

2. Anderson, T., \& Dron, J. (2011). Three generations of distance education pedagogy. The International Review of Research in Open and Distributed Learning, 12 (3), 80-97.

3. Armstrong, T. (1999). Seven kinds of smart: Identifying and developing your multiple intelligences. New York: Penguin Putnam Inc.

4. Armstrong, T. (2000). Multiple intelligences in the classroom (2nd ed.). Alington, VA: Association for Supervision and Curriculum Development

5. Bandura, A. (1997). Self-efficacy: The exercise of control. New York: Freeman.

6. Collins, R. (2014). Skills for the 21st Century: teaching higher-order thinking. Curriculum \& Leadership Journal, 12(14).

7. Djaali dan Pudji Mulyono (2008). pengukuran dalam bidang pendidikan. Jakarta. Grasindo.

8. Doolittle, Peter E., Triplett Hicks D, Nichols C.F., W.D., \& Carl A Young, (2012). Reciprocal Teaching for Reading Comprehension in Higher Education: A Strategy for Fostering the Deeper Understanding of Texts. International Journal of Teaching and Higher Education, 17 (2), 2012. http://www.isetl.org/iitlhe/.

9. Dolati, Z., \& Tahriri, A. (2017). EFL teachers' multiple intelligences and their classroom practice. SAGE Open, 7(3), 2158244017722582.

10. Gardner, H. (2011). Frames of mind: The theory of multiple intelligences. Hachette UK.

11. Gardner, H. (1999). Intelligence reframed: Multiple intelligences for the 21st century. New York: Basic Books.

12. Gillies, R. M. (2014). Dialogic interactions in the cooperative classroom. International Journal of Educational Research, 76, 178-189. https://doi.org/10.1016/ j.ijer.2015.02.009

13. Hurian Rahman (2014). Pengembangan Profesi Pendidikan IPS. Bandung: Alfabeta. 
14. Janiafer R Seymour dan Helena P Osana, Reciprocal teaching procedure and principles: two teachers developing understanding, (2013) teaching and teacher education journal (19); Elsevier: hh. 325-344

15. Krathwohl, D. R., \& Anderson, L. W. (2010). Merlin C. Wittrock and the revision of Bloom's taxonomy. Educational Psychologist, 45(1), 64-65.

16. McCulley, L. V., \& Osman, D. J. (2015). Effects of reading instruction on learning outcomes in social studies: A synthesis of quantitative research. Journal of Social Studies Research, 39(4), 183-195. https://doi.org/10.1016/ j.jssr.2015.06.002

17. Mulyono, D., Asmawi, M., \& Nuriah, T. (2018). The Effect of Reciprocal Teaching, Student Facilitator and Explaining and Learning Independence on Mathematical Learning Results by Controlling the Initial Ability of Students, 13(3), 199-205.

18. Mohammad Reza Ahmadi dan Abbas Pourhossein Gilakjani (2012). Reciprocal Teaching Strategies and Their Impacts on English Reading Comprehension. Theory and Practice in Language Studies Journal), 2 (10), Finland: http://www.isetl.org/ijtlhe/.

19. Mirzaei, A., Rahimi Domakani, M., \& Heidari, N. (2014). Exploring the relationship between reading strategy use and multiple intelligences among successful L2 readers. Educational Psychology, 34(2), 208-230.

20. Marzano, R. J., \& Heflebower, T. (2011). Teaching \& assessing 21st-century skills. Solution Tree Press.

21. Ormrod, J. E., Anderman, E. M., \& Anderman, L. H. (2016). Educational psychology: Developing learners. Pearson.

22. Ollila, J., \& Macy, M. (2019). Social studies curriculum integration in elementary classrooms: A case study on a Pennsylvania Rural School. Journal of Social Studies Research, 43(1), 33-45. https://doi.org/10.1016/ j.jssr.2018.02.001

23. Palinscar, A., \& Brown, A. L. (2012). Reciprocal teaching. International guide to student achievement, 369.

24. Pehmer, A. K., Gröschner, A., \& Seidel, T. (2015). Fostering and scaffolding student engagement in productive classroom discourse: Teachers' practice changes and reflections in light of teacher professional development. Learning, Culture, and Social Interaction, 7, 12-27. https://doi.org/10.1016/ j.lcsi.2015.05.001

25. Ronfeldt, M., Farmer, S. O., McQueen, K., \& Grissom, J. A. (2015). Teacher collaboration in instructional teams and student achievement. American Educational Research Journal, 52(3), 475-514.

26. Schunk, D. H. (2012). Learning theories an educational perspective sixth edition.

27. Safaria, T. (2005). Interpersonal intelligence: Metode pengembangan kecerdasan interpersonal anak. Yogyakarta: Amara Books.

28. Slavin, R. E. (2012). Educational Psychology: Theory and Practice. 10th-ed.

29. Shoda, T. M., \& McConnell, A. R. (2013). Interpersonal sensitivity and self-knowledge: Those chronic for trustworthiness are more accurate at detecting it in others. Journal of Experimental Social Psychology, 49(3), 440-443. https://doi.org/10.1016/j.jesp.

30. Suhaimi, A. W., Marzuki, N. A., \& Mustaffa, C. S. (2014). The Relationship between Emotional Intelligence and Interpersonal Communication Skills in Disaster Management Context: A Proposed Framework. Procedia - Social and Behavioral Sciences, 155(October), 110 114. https://doi.org/10.1016/j.sbspro. 2014.10.265

31. Susanto, A. (2014). Pengembangan Pembelajaran IPS di SD. Kencana.

32. Spörer, N., Brunstein, J. C., \& Kieschke, U. L. F. (2009). Improving students' reading comprehension skills:
Effects of strategy instruction and reciprocal teaching. Learning and instruction, 19(3), 272-286.

33. Tirri, K., Nokelainen, P., \& Komulainen, E. (2013). Multiple intelligences: Can they be measured?. Psychological Test and Assessment Modeling, 55(4), 438.

34. Vygotsky, L. (1978). Mind in society. Cambridge, Mass. MIT Press.

35. Wahab, A. A., \& Sapriya, S. (2011). Theory and Platform for CivicEducation. Bandung: Alfabeta.

36. Widyasari, F. (2016). The Correlation between Reading Attitude, Interpersonal, and Reading Comprehension. Ssrn, (2), 288-298. https://doi.org/10.2139

37. Yun Fen Yang (2010). Developing a Reciprocal Teaching for College Remedial Reading Instruction Computer and Education Journal, Vol. 22, No. pp. 1193-1201.

38. Zimmerman, B. J. (2000). Attaining self-regulation: A social cognitive perspective. In M. Boekaerts, P. R. Pintrich, \& M.

39. Zendler, A., \& Reile, S. (2018). The effect of reciprocal teaching and programmed instruction on learning outcome in computer science education. Studies in Educational Evaluation, 58(May), 132-144. https://doi.org/10.1016/j.stueduc. 2018.05.008 